\title{
THE RELATIONSHIP OF HOSPITAL COST, SERVICE QUALITY, AND PATIENT SATISFACTION
}

\author{
Riska Arsita, Haerawati Idris \\ Department of Health Policy and Administration, \\ Faculty of Public Health Universitas Sriwijaya
}

\begin{abstract}
Customer satisfaction becomes very important to determine the success of service companies. One way to survive in the healthcare industry today is to create customer satisfaction through improved service quality. Hospital cost is an indicator for patients to utilize health services. This study aims to analyze the relationship of hospital cost and service quality with patient satisfaction. This study used analytic survey with a cross-sectional study design. The sample of this study is the general patient who used inpatient and outpatient installation of Bhayangkara Hospital in Palembang as many as 117 patients. The sampling technique used systematic random sampling. Analysis of statistical data used the t-test. The results showed that the quality of service has a significant relationship with patient satisfaction (p-value 0,001). While the hospital cost does not have a significant relationship with satisfaction patients (p-value 0,368). Service quality has relationship with patient satisfaction. The hospital should improve dimension of service quality in order to improve patient satisfaction.
\end{abstract}

Keywords: Cost, Service Quality, Patient Satisfaction

\section{HUBUNGAN PERSEPSI TARIF DAN KUALITAS PELAYANAN DENGAN KEPUASAN PASIEN \\ ABSTRAK}

Kepuasan konsumen menjadi hal yang sangat penting untuk menentukan keberhasilan perusahaan jasa. Salah satu cara untuk bertahan di industri kesehatan saat ini adalah menciptakan kepuasan pelanggan melalui peningkatan kualitas jasa. Tarif merupakan indikator bagi pasien untuk memanfaatkan jasa pelayanan kesehatan. Penelitian ini bertujuan untuk menganalisis hubungan persepsi tarif dan kualitas pelayanan dengan kepuasan pasien. Survei analitik dengan studi cross sectional. Sampel yang digunakan sebanyak 117 pasien yang ada di instalasi rawat inap dan rawat jalan Rumah Sakit Bhayangkara Palembang dengan teknik pengambilan sampel secara systematic random sampling. Analisis data statistik menggunakan uji t test. Hasil penelitian menunjukkan bahwa kualitas pelayanan mempunyai hubungan yang signifikan dengan kepuasan pasien (p-value 0,001). Sedangkan tarif tidak mempunyai hubungan yang signifikan dengan kepuasan pasien (p-value 0,368).Kualitas layanan memiliki hubungan dengan kepuasan pasien. Rumah sakit harus meningkatkan dimensi kualitas layanan untuk meningkatkan kepuasan pasien.

Kata Kunci: Biaya, Kualitas Pelayanan, Kepuasan Pasien.

Correspondece Address: Haerawati Idris Jl. Palembang Prabumulih KM 32, Indralaya Kabupaten Ogan Ilir, Sumatera Selatan Email: haera@fkm.unsri.ac.id 


\section{INTRODUCTION}

Healt need is increasing now. Public awareness of the importance of health. ${ }^{1}$ Increasing public awareness, as well as the rapid development in medical technologi. The this becomes a demand for quality health services in order to meet the basic needs of the community. $^{2}$

Quality services are equally important needed for organizations and also the public sector. Three crucial factors must be considered to face competition to meet patient satisfaction, namely service quality, cost, and facilities. ${ }^{1}$ Quality of care can be determined by comparing the perceptions of consumers on the real service they get with a service which they received, or they expect to attributes of an enterprise service. ${ }^{3}$ Service quality must start from customer needs and end on customer perception, where customer perception of service quality is a comprehensive assessment of the excellence of service. ${ }^{4}$

Hospital cost is a definite element and becomes an indicator for patients in utilizing health services. Patients must want to get good health care, following the amount of charge that is issued to meet the needs and expectations. Determination of cost service and also efforts to improve the quality of services following patient expectations will have an impact on patient satisfaction. ${ }^{5}$ Cost is the value of a service determined by a number of measures of money based on the consideration that a hospital is willing to provide services to patients through that value of money. ${ }^{6}$

The hospital is a service institution that conducts complete individual health services that provide a variety of services, including inpatient, outpatient, and emergency services. Comprehensive health services are health services that include promotive, preventive, curative, and rehabilitative activities. ${ }^{7,8}$ Hospital must be able to place their orientation on customer satisfaction. Consumer satisfaction is very important because it determines the success of a service company. ${ }^{9}$

Several studies related to tariffs and service quality with patient satisfaction show that service cost and quality have a positive and significant effect on patient satisfaction. ${ }^{1,9,10}$ This study aims to analyze the relationship cost and quality of service with patient satisfaction at Bhayangkara Hospital Palembang.

\section{METHOD}

The research design used in this study is a quantitative method analytic survey research with cross-sectional study design. ${ }^{11}$ Costs and service quality are independent variables in this study, while the dependent variable is patient satisfaction at the Bhayangkara Hospital in Palembang.

The data in this study were obtained through direct interviews with respondents using a questionnaire. The population in the study were general patients in inpatient and outpatient installations with a sample of 117 patients. The technique in sampling is done by systematic random sampling. ${ }^{12}$ Data analysis techniques were performed using statistical software with univariate and bivariate analysis tests with t-test (partial test). Measurement of satisfaction using the Pohan formula, which compares the components of patient expectations and components of health service performance. ${ }^{13}$

\section{RESULT \\ Univariate Analysis \\ Characteristics of Respondents}

Based on research that has been done, it can be seen that the characteristics of respondents are as follows: 
Table 1.

Distribution of Respondent Characteristics at Bhayangkara Hospital Palembang

\begin{tabular}{llcl}
\hline \multicolumn{1}{c}{ Characteristics } & \multicolumn{1}{c}{ Category } & $\begin{array}{c}\text { Frequency } \\
(\mathbf{n = 1 1 7})\end{array}$ & $\mathbf{( \% )}$ \\
\hline Age & S40 years & 61 & 52.1 \\
Gender & M 40 years & 56 & 47.9 \\
Level of education & Male & 49 & 41.9 \\
& Female & 68 & 58.1 \\
& Elementary school & 22 & 18.8 \\
& Junior high School & 23 & 19.7 \\
& Senior high school & 49 & 41.9 \\
& Diploma & 14 & 12.0 \\
Work type & S1 & 8 & 6.8 \\
& S2 & 1 & 0.9 \\
& Civil servants & 12 & 10.3 \\
& Private employees & 18 & 15.4 \\
& entrepreneur & 28 & 23.9 \\
& TNI / Polri & 3 & 2.6 \\
& Student / Student & 7 & 6.0 \\
& Housewife & 29 & 24.8 \\
& Does not work & 20 & 17.1 \\
Frequency of treatment & One time & 36 & 30.8 \\
& Twice & 45 & 38.5 \\
& Three times & 17 & 14.5 \\
& More than three times & 19 & 16.2 \\
Never treated & Ever & 63 & 53.8 \\
& Never & 54 & 46.2 \\
\hline
\end{tabular}

The table 1 shows that the majority of respondents seeking treatment at Bhayangkara Hospital Palembang were patients in the age category $\leq 40$ years $(52.1 \%)$. The majority of sex is female $(58.1 \%)$. For the last category of education, the majority were high school (41.9\%). Most respondents' occupation was a housewife $(24.8 \%)$. Based on the frequency of treatment of patients, patients with a frequency of treatment were twice with a percentage of
$38.5 \%$. Based on the category of being treated in other hospitals before, respondents were already treated with a percentage of $53.8 \%$.

\section{Patient Satisfaction}

The table below presents a comparison between the level of expectation of respondents with the reality of patient satisfaction at Bhayangkara Hospital in Palembang. 
Table 2.

Distribution of Respondents' Compliance Levels About Patient Satisfaction

\begin{tabular}{lccc}
\hline \multicolumn{1}{c}{ Statement } & Reality Score & $\begin{array}{c}\text { Expectation } \\
\text { Score }\end{array}$ & $\begin{array}{c}\text { Conformity } \\
\text { Level (\%) }\end{array}$ \\
\hline $\begin{array}{l}\text { I feel happy to have received treatment at } \\
\text { Bhayangkara Hospital }\end{array}$ & 505 & 528 & 96,21 \\
$\begin{array}{l}\text { Services were given a nurse at } \\
\text { the hospital Bhayangkara are following } \\
\text { expectations }\end{array}$ & 500 & 514 & 97,28 \\
$\begin{array}{l}\text { The ability and knowledge of doctors at } \\
\text { Bhayangkara Hospital is in line } \\
\text { with expectations }\end{array}$ & 502 & 524 & 95,80 \\
$\begin{array}{l}\text { The overall service of Bhayangkara Hospital to } \\
\text { patients is in line with expectations }\end{array}$ & 454 & 501 & 90,62 \\
$\begin{array}{l}\text { The overall service of Bhayangkara hospital to } \\
\text { the patient in line with expectation }\end{array}$ & 512 & 530 & 96,60 \\
\hline & & & 95,30 \\
\hline
\end{tabular}

The table 2 shows that the overall suitability level is $95.30 \%$. If the patient's expectations are the same as the health service performance or the patient's satisfaction level is $100 \%$, then the patient must be satisfied. This means that patient satisfaction at the Bhayangkara Hospital in Palembang is $95.30 \%$. The rest shows patient dissatisfaction at 4.7\%. On the question indicator regarding the service tariff determined by Bhayangkara Hospital is following the service received is lower than the overall suitability level, that is $90.62 \%<95.30 \%$.

\section{Perception of Cost Hospital}

Based on the results of univariate analysis, the perception of health service tariffs at Bhayangkara Hospital Palembang, namely: $(76.1 \%)$. The cost of health services is in accordance with the quality of services provided by the hospital to patients, (69.2\%) patients stated that the cost of care was affordable and in accordance with the benefits and value obtained, (72.6\%) patients stated the cost of medicines in Bhayangkara Hospital in accordance with the ability of the patient's purchasing power (affordable).

\section{Quality of Service}

The quality of service at Bhayangkara Hospital Palembang divided in some dimension. The percentage of physical appearance (tangible) at Bhayangkara Hospital Palembang, namely: (41.9\%) patients stated that cleanliness, neatness, and beauty of the treatment room was excellent, (59.8\%) support facilities located in the treatment room is already full, $(59.8 \%)$ state examination room a comfortable room, and 48.7\% appearance nurses and doctors at the Hospital Bhayangkara Palembang clean and tidy.

Empathy (empathy) at Bhayangkara Hospital Palembang namely: (59.0\%) doctors provide information needed by patients, $(59.0 \%)$ doctors and nurses care and attention to patient complaints, $(59,0 \%)$ the registration and payment system greatly facilitates patients, (56.4\%) the services provided are carried out fairly without regard to social and economic status. 
Reliability (reliability) in the hospital Bhayangkara Palembang (44.4\%) patient examination procedures are not complicated, $(62.4 \%)$ information provided to patients is accurate, (43.6\%) doctor's examination right and as scheduled, (47.0\%) the readiness of doctors in serving is in accordance with the procedure.

Variable of responsiveness at Bhayangkara Hospital Palembang, namely: $(36.8 \%)$ nurses are responsive in resolving patient complaints, $(46.2 \%)$ doctors provide services according to patient needs, $(41,9 \%)$ doctors are responsive in resolving patient complaints, (63.2\%) laboratory/radiology officers serve politely and friendly and are responsive.

Assurance variable showed that: (53.8\%) while waiting for the patient to register/register of regular, $(53.0 \%)$ of nurses skilled in carrying out its duties, (40.2\%) medical service creates a feeling safe and trusting, (39.3\%) doctors and nurses are friendly.

\section{Bivariate Analysis}

Bivariate analysis is performed to see whether there is a relationship between the independent variables, which include perception of hospital cost and service quality with the dependent variable that is patient satisfaction. This bivariate analysis was performed using the t-test.

Table 3.

t-Test Analysis

\begin{tabular}{cccc}
\hline Variable & Average & t & Sig \\
\hline Hospital cost & 9.56 & $-0,904$ & 0.368 \\
Quality service & 84.14 & 3,372 & 0.001 \\
\hline
\end{tabular}

Based on the table 3, it can be shown that the results of the study indicate that variables that have a positive and significant relationship are service quality variables. Obtaining a significant value of $0.001(0.001<0.05)$ means that the partial significance of service quality has a significant relationship to patient satisfaction. $\mathrm{T}$ value count of 3.372. It is meant, count $(3,372)>$ $\mathrm{t}_{\text {table }}(1,980)$ it can be concluded that the service quality variable has a contribution to patient satisfaction. The magnitude of the relationship between service quality and patient satisfaction can be seen from the Beta value of 0.314 or $31.4 \%$. This means that the magnitude of the relationship between service quality and patient satisfaction is $31.4 \%$, which indicates a positive and significant value.

\section{DISCUSSION \\ Patient Satisfaction}

Based on the results of the study the relationship between perception of tariff and service quality with patient satisfaction variables that have a significant relationship to patient satisfaction is service quality while variable hospital cost does not have a significant relationship to patient satisfaction. The results of the study of the level of congruence between expectations and reality for the satisfaction variable showed the highest percentage was an indicator of the services provided by nurses at Bhayangkara Hospital that were in line with expectations. This is in line with research conducted by Suaib, which states that indicators that influence satisfaction are the services of nurses. ${ }^{14}$ Patient dissatisfaction arises because of the gap between patient expectations and the performance of health services that he gets when using health services. ${ }^{15}$

\section{Hospital Cost}

According to Swastha, consumers' perceptions of the quality of a product can change along with changes in the cost. ${ }^{16}$ Based 
on the results of research that has been done shows that service cost has no effect and do not have a significant relationship to patient satisfaction.

This study is not in line with research conducted by Adil, stating that the price variable has a significant direct effect on patient satisfaction. ${ }^{17}$ Research conducted by Hartini states that cost has a positive and significant effect on patient satisfaction. This means that the more competitive the cost set by the hospital and following the services provided, patient satisfaction will increase as well. ${ }^{18.19}$

The results of this study are in line with research conducted by Yusuf, which shows that there is no meaningful relationship between cost and patient satisfaction. ${ }^{3}$ According to Hutabarat and Hosang et al. in their research showed to influence the cost of service to the level of patient satisfaction is not significant. ${ }^{4.20}$

\section{Service Quality}

Based on the results of the research, it was found that the probability of p-value was 0.001 , which means that partially the quality of service had a significant relationship to patient satisfaction at Bhayangkara Hospital in Palembang. This is in line with the theory of Parasuraman et al., which explains that the

\section{REFERENCES}

1. Sismiyati A. Analisis Pengaruh Kualitas Pelayanan, Tarif dan Fasilitas terhadap Kepuasan Pasien (Studi pada Pasien RSKIA Ummi Khasanah Bantul). Prodi Manajemen UPY. 2017.

2. Afriadi, Y., \& Sitohang, S. Pengaruh Kualitas Layanan, Harga, dan Fasilitas Terhadap Kepuasan Pasien Rawat Inap. Jurnal Ilmu \& Riset Manajemen, 2016;5(6).

3. Zeithaml L, Valerie Parasuraman A, Zeithaml VA, Berry LL. Servqual: A multiple-item scale for measuring quality of services is centered on efforts to meet the needs and desires of customers and the accuracy in delivery to offset customer expectations. ${ }^{21}$ According to Sudian, the success obtained from a health service is very closely related to patient satisfaction in improving the quality of its services. ${ }^{22}$ This study is in line with research conducted by Handayani and Irianto, which shows a positive and significant relationship between service quality and patient satisfaction. ${ }^{23.24}$

\section{CONCLUSION}

Based on the results of research that has been done, variable hospital cost does not have a statistically significant relationship with patient satisfaction. Whereas service quality has a statistically significant relationship with patient satisfaction. Police Hospitals are advised to Palembang to perform communication with the patient in order to reduce the gap between the expectations of the performance of health services and conduct patient satisfaction surveys every year in order to determine the level of patient satisfaction. It is hoped that further research will be more varied by using various variables that are closely related to patient satisfaction.

consumer perc. Journal of retailing. 1988 Apr 1;64(1):12.

4. Kotler P, Keller KL. Manajemen Pemasaran Edisi 13. Jakarta: Erlangga. 2009.

5. Hutabarat, J. Analisis Hubungan Antara Tarif Pelayanan Dan Kualitas Layanan Serta Pengaruhnya Terhadap Tingkat Kepuasan Kelompok Pasien Umum Di Klinik "AN" Bandung, universitas komputer indonesia, 2012;112 (1-19).

6. Trisnantoro L. Memahami Penggunaan Ilmu Ekonomi dalam Manajemen Rumah 
Sakit. UGM press; 2018 Jul 25.

7. Undang-Undang Republik Indonesia Nomor 44 tahun 2009 Tentang Rumah Sakit.

8. Peraturan Menteri Kesehatan Republik Indonesia Nomor 56 Tahun 2014 Tentang Klasifikasi Dan Perizinan Rumah Sakit.

9. Safitri DN, Hidayat W, Dewi RS. Pengaruh Kualitas Pelayanan, Lokasi, Dan Tarif Terhadap Kepuasan Pasien Rawat Inap Rumah Sakit Lestari Raharja Kota Magelang (Studi Kasus Pada Pasien Rawat Inap Non Asuransi). Jurnal Ilmu Administrasi Bisnis. 2015;4(2):325-31.

10. Kusuma EW, Suryoko S, Budiatmo A. Pengaruh Tarif Dan Kualitas Pelayanan Terhadap Kepuasan Pasien Rawat Inap Di RSUD Raa Soewondo Pati. Jurnal Ilmu Administrasi Bisnis. 2014;3(4):260-6.

11. Notoatmodjo S. Metodologi Penelitian Kesehatan (Cetakan VI). Jakarta: Penerbit PT. Rineka Cipta. 2012.

12. Lapau B. Metode Penelitian Kesehatan: Metode Ilmiah Penulisan Skripsi (Doctoral Dissertation, Tesis, dan Disertasi. Jakarta: Yayasan Pustaka Obor Indonesia). 2012.

13. Pohan IS. Jaminan Mutu Layanan Kesehatan: Dasar-Dasar Pengertian dan Penerapan. Jakarta: EGC. 2007.

14. Suaib I, Jafar N. Pengaruh Kualitas Pelayanan terhadap Kepuasan Pasien di Ruang Rawat Inap RSUD Syekh Yusuf Kabupaten Gowa. Fakultas Kesehatan Masyarakat Universitas Hasanudin. (Skripsi). 2011

15. Swastha B. Irawan. Manajemen Pemasaran Modern. 2005.

16. Adil A, Syamsun M, Najib M. Pengaruh Kualitas Pelayanan dan Biaya terhadap Kepuasan dan Loyalitas Pasien RSUD Kota Bogor. Jurnal Aplikasi Manajemen. 2016 Sep 1;14(3):432-41.

17. Hartini S. Pengaruh Tarif Rawat Inap,
Kualitas Pelayanan Dan Promosi Terhadap Kepuasan Pasien Di RSU Jati Husada Karanganyar (Doctoral dissertation, Universitas Muhammadiyah Surakarta).

18. Vebnia A, Pradhanawati A, Nurseto S. Pengaruh Fasilitas, Lokasi dan Tarif terhadap Loyalitas melalui Kepuasan Pasien sebagai Variabel Mediasi pada Pasien Poli Rumah Sakit Muhammadiyah Semarang. Jurnal Ilmu Administrasi Bisnis. 2013;2(4):190-7.

19. Yusuf H. Hubungan Pelayanan Petugas dan Tarif dengan Kepuasan Pasien Kelas III di Rumah Sakit Umum Mokopido Kabupaten Tolitoli. Promotif: Jurnal Kesehatan Masyarakat. 2016;6(2):72-9.

20. Hosang N. Analisis Pengaruh Kualitas Pelayanan dan Harga Terhadap Kepuasan Pasien (Studi Kasus pada Rumah Sakit Siloam Manado). Jurnal Berkala Ilmiah Efisiensi. 2016 Jan 22;16(1).

21. Sudian T. Hubungan Kepuasan Pasien terhadap Mutu Pelayanan Kesehatan di Rumah Sakit Cut Mutia Kabupaten Aceh Utara. Aceh Utara. 2011.

22. Handayani SB, Iriyanto S. Pengaruh Kualitas Pelayanan dan Tarif terhadap Kepuasan serta Implikasinya terhadap Minat Beli Pasien Rawat Inap pada Rumah Sakit Roemani Muhammadiyah Semarang. Jurnal stiedharmaputra. 2010;3(2):1.

23. Martina. Pengaruh Kualitas Pelayanan Kesehatan Terhadap Kepuasan Pasien Rawat Inap RSUD Cut Meutia Kabupaten Aceh Utara. Fakultas Ilmu Sosial dan Ilmu Politik Universitas Sumater Utara. (Tesis). 2011

24. Yuniarti S. Hubungan Antara Kualitas Pelayanan Rumah Sakit dengan Tingkat Kepuasan Pasien BPJS di Ruang Perawatan RSUD Sultan Syarif Mohamad Alkadrie Kota Pontianak Tahun 2015. Jurnal ProNers. 2015 Aug 12;3(1). 